\title{
Kıbrıs Barış Harekâtı'nda Türkülerin Propaganda Amaçlı Kullanılması: "Kıbrıs'a Çıktık" Türküsü Üzerine İnceleme
}

\section{The Use for the Purpose of Propaganda of the Folk Songs in the Cyprus Peace Operation: An Examination of the Folk Song "Kıbrıs'a Çıktık"}

\section{Dr. Öğr. Üyesi Sadık Çalışkan ${ }^{1}$ - Doç. Dr. Derya Karaburun Doğan²}

Başvuru Tarihi: 03.11.2019

Kabul Tarihi: 16.06 .2020

Makale Türü: Araştırma Makalesi

Öz

Çalışma kapsamında Kıbrıs'a Çıktık adlı türkünün Türk milliyetçiliğinin ön plana çıkarılmasında ve Yunanistan karşıtı kamuoyunun inşasında propaganda amaçlı ne şekilde kullanıldığı ortaya konulmaya çalışılmıştır. Bu amaçla türkü nitel araştırma yöntemlerinden müzik ve göstergebilim analizleri kullanılarak incelenmiştir. Çalışmada eser, ABD'li dilbilimci Charles Sanders Peirce'in Anlamlandırma Modeli ve Fransız antropolog Claude Lévi-Strauss'un İkili Karşıtlıklar Modeli ışığında analiz edilmiştir. Elde edilen bulgularda, eserde Rumlara yönelik düşman soyut kavramı kullanılarak olumsuz bir algı inşa edildiği ortaya çıkarılmıştır. Kıbrıs Barış Harekâtı esnasında ve daha sonrasında Türk ozan, âşık ve şarkıcılar tarafından milliyetçilik fikrini daha etkili kılmak için olumsuz temsiller içeren eserlerin yazıldı̆̆ $v$ ve icra edildiği gözlemlenmiştir. Analiz sonucunda eserin "La (Dügâh)” karar sesinden, "Uşşak dörtlüsü̈ne, "Buselik beşlisi” nin eklenmesinden oluşan Geleneksel Türk Sanat Müziği makam dizilerinden "Uş̧̧ak Makamı Dizisi”nde, ritmik yapı bakımından "2/4 (Nim Sofyan)" usulünde icra edildiği sonuçlarına varılmıştır.

Anahtar Kelimeler: Kıbrıs Barış Harekâtı, Yunanistan, Nefret Söylemi, Türkü, Propaganda

\begin{abstract}
In the context of the study, it was tried to reveal how Turkish folk music called Kıbrıs'a Çıktık was used to highlight the Turkish nationalism and to construct anti-Greece public opinion for propaganda purposes. For this purpose, folk songs were examined by using music and semiotics analysis in qualitative research methods. In this study, the study was analyzed in the light of the Meaning Model of the American linguist Charles Sanders Peirce and the Binary Contrasts Model of the French anthropologist Claude Lévi-Strauss. In the findings obtained, it was revealed that a negative perception was built by using enemy abstract concept towards Greeks in the study.
\end{abstract}

\footnotetext{
${ }^{1}$ İnönü Üniversitesi, İletişim Fakültesi, sadik.caliskan@inonu.edu.tr, ORCID ID: 0000-0001-6899-0424.
}

2 İnönü Üniversitesi, Devlet Konservatuarı, dkaraburun@inonu.edu.tr, ORCID ID: 0000-0001-9091-5957 
During and after the Cyprus Peace Operation, it was observed that songs including negative representations were written and performed by Turkish poets, lovers and singers in order to make the idea of nationalism more effective. As a result of the analysis, it was found that the folk song was performed with 2/4 (Nim Sofyan) tempo in terms of rhythmic structure in the sound decison "La (Dügâh)" in "Ussak Quartet" consisting of "Buselik Quintette" in the "Ussak Mode" in mode series of Traditional Turkish Art Music.

Keywords: Cyprus Peace Operation, Greece, Hate Speech, Folk Song, Propaganda

\section{Giriş}

11 Ekim 1922 tarihinde imzalanan Mudanya Ateşkes Antlaşması ile birlikte Türkiye ve Yunanistan arasındaki savaş hali resmi olarak son bulmuştu. Bu tarihten itibaren her iki ülke de ilişkilerini geliştirmeye yönelik karşılıklı önemli adım atmıştı. Buna karşın 1960 yllında Büyük Britanya İmparatorluğu'nun Kıbrıs'tan çekilmesi ile birlikte iki ülke arasında Kıbrıs önemli bir sorun olarak ortaya çıkmıştı. 15 Temmuz 1974 tarihinde Kıbrıs'ta Nikos Sampson önderliğindeki bir grup Rum subayın yönetimi ele geçirmesiyle birlikte, Türkiye ve Yunanistan arasındaki ilişkiler, Kurtuluş Savaşı'ndan sonraki en gerilimli dönemini yaşamıştı. Bu süreçte Türk medyasında Yunanistan karşıtı sert söylemler yer almaya başlamıştı. Aynı zamanda Yunan ordusunun Kıbrıslı Türkleri katlettiğini belirten türküler bestelenmeye başlanmıştı. Bestelenen türkülerde milliyetçilik söylemlerinin yanında Yunanistan'a karşı olumsuz algıya yol açan ifadelere de sıklıkla yer verilmişti. Bu türkülerden biri de Bedia Akartürk tarafından seslendirilen Kıbrıs'a Çıktık adlı eser olmuştu. Dönemin en popüler türkülerinden biri haline gelen eser, Türk halkının milliyetçilik duygularının harekete geçirilmesinde ve Kıbrıs'taki darbecilere karşı kazanılan zaferleri yansıtmasında propaganda amaçlı etkili bir şekilde kullanılmıştır. Çalışmada Kıbrıs'a Çıktık adlı eserin müzik ve göstergebilim analizleri yapılarak, Türk kamuoyunun Kıbrıs Barış Harekâtı sırasında Yunanistan'a yönelik bakış açısının ortaya çıkarılması amaçlanmaktadır.

Son dönemde müzik analizi yöntemi kullanılarak propaganda şarkıları üzerine göstergebilimsel incelenmelerde bulunan ulusal alanda önemli akademik çalışmaların yapıldığı görülmektedir. Bunlar içerisinde; Karaburun Doğan vd. (2017), 1999 Türkiye'deki Genel ve Yerel Seçimleri'nde siyasal partilerin propaganda müziklerini, Çakı ve Karaburun Doğan (2018), Türk Sanat Müziği Vicdân-1 Muâzzam üzerinden İttihat ve Terakki propagandasını; Karaburun Doğan ve Çakı (2019), Girne'den Yol Bağladık Anadolu'ya Şarkısı üzerinden müziğin milliyetçilik boyutunda propaganda amaçlı kullanılmasını göstergebilim yöntemi kullanarak incelemektedir

Kıbrıs Barış Harekâtı sırasında bestelenen türkülerde;

- Türk ve Yunan halkı hangi soyut kavramlar üzerinden temsil edilmektedir?

- Yunanistan'a karşı hangi mitler oluşturulmaktadır?

- Yunanistan karşı inşa edilen nefret söylemi hangi temellere dayandırılmaktadır?

- müzik kitleleri hareke geçirmede ne amaçla kullanılmıştır? 


\section{Propagandada Nefret Söylemi}

Nefret söylemi, nefreti, düşmanlığını, saldırganlığı, ulusalcılık ve etnik merkezciliği, ayrımcılığı ve hoşgörüsüzlüğü yayan, kışkırtan veya meşrulaştıran her türlü ifade biçimi olarak tanımlanmaktadır (Weber, 2009, s. 3; Ozulu, 2014, s. 18). Nefret söylemi, nefretin birey tarafindan eyleme dönüştürülmüş halini ifade etmektedir. Bir kişiye ve gruba karşı oluşturulan önyargı, korku ve nihayetinde nefretin, doğrudan ortaya çıkarılmasıdır (Waldron, 2012, s. 34). Nefret söylemi rrk, etnik kimlik, din, yaş, cinsiyet, fiziksel durum, engellilik, cinsel tercih gibi pek çok farklı konu üzerinden gerçekleştirilebilmektedir (Cortese, 2006, s. 1). İnsanların toplu yaşamaya başladıkları dönemden itibaren gruplaşmalar meydana gelmiştir. Bu gruplaşmalarda zamanla "biz" ve "onlar" kavramları ortaya çıkmıştır. Toplumlar kimi zaman kendilerinden olmayanları ötekileştirmiş, dışlamış ve nihayetinde onları düşman olarak nitelendirmiştir. $\mathrm{Bu}$ aşamada toplumlar, kendilerinden farklı olan gruplara yönelik nefret söylemine yönelebilmiştir (Vardal, 2015, s. 135). Nefret söyleminin geniş kitlelere yayılmasında da kitle iletişim araçları etkili bir rol oynamaktadır (Kuş, 2016, s. 99). Özellikle medya kanalıyla belirli bir gruba yönelik doğrudan nefret söylemi içerikli propaganda faaliyetine girişilebilmektedir.

Propaganda, belirli bir ideolojin, fikrin, idealin veya görüşün kitle iletişim araçlarından yararlanılarak kaynaktan alıcıya tek yönlü bir iletişim formatında kitlelere aktarılmasını, bu fikirlerin kitleler tarafından kabul edilmesini ve kabul edilen fikirler doğrultusunda kitlelerin harekete geçmesini amaçlayan ikna odaklı bir iletişim türünü ifade etmektedir. Propaganda totaliter yönetimlerde ön plana çıkmaktadır (Karaca, 2018, s. 1208). Nefret söylemi, propaganda amaçlı kullanıldığında kitlelerin belirli bir gruba karşı birlik olması ve hatta o gruba karşı harekete geçmesi amaçlanmaktadır. Tarihte dünyanın pek çok farklı coğrafyasında belirli gruplara yönelik nefret söylemi kullanılmıştır. Buna karşın 20. yüzyılda kitle iletişim araçlarında yaşanan devrim niteliğindeki gelişmelerle birlikte nefret söylemi propaganda faaliyetlerinde ön plana çıkmaya başlamıştır.

20. yüzyılda propaganda faaliyetlerinde topyekûn bir nefret söylemi Birinci Dünya Savaşı sırasında İngiltere'de Alman İmparatorluğu'na karşı kullanılmıştır. İngiltere'de bulunan Savaş Propaganda Bürosu (Wellington House), kitleleri Alman ordusuna karşı harekete geçirebilmek adına Alman askerlerini barbar katiller olarak kamuoyuna sunmuştur. Özellikle Alman ordularının 1914 yılında Belçika'yı işgalini Alman ordularına karşı nefret söylemi oluşturmada etkili bir şekilde kullanmıştır. Bu süreçte İngiliz propagandası, Almanların Belçika'da insanlık dışı uygulamalara yöneldiğini anlatan hikayeler yayınlamıştır. Yayınlanan hikayelerde Alman askerlerinin vahşete varan boyutta uygulamalara yöneldiği iddia edilmiştir (Tate, 1998, s. 42). İkinci Dünya Savaşı'nda da nefret söylemi inşasından propaganda amaçlı sı sık yararlanılmıştır. Müttefik Devletleri'nin propaganda faaliyetlerinde, Mihver Devletleri'nin liderleri ve orduları itibarsızlaştırılmaya çalışılmış (Yılmaz, 2020, s.547), benzer şekilde Mihver Devletleri propaganda faaliyetlerinde Müttefik Devletleri'ni sert bir şekilde eleştirmiştir (Gazi ve Çakı, 2019, s.251). Özellikle bu dönemde Nazi Almanyası'nda Yahudilere karşı yürütülen propaganda faaliyetlerinde yoğun bir şekilde nefret söylemine yönelinmiştir (Jowett ve O'donnell, 2014, s. 245). Bu aşamada Nazi Almanyasi'nda egemen olan Nazizm ideolojisinin antisemitist söylemleri, Yahudilere karşı oluşan nefret söyleminin kaynağı haline gelmiştir (Voigtländer ve Voth, 2015, s. 7931). Soğuk Savaş döneminde Batı ve Doğu Bloğu üyesi ülkeler 
arasında yürütülen propaganda faaliyetlerinde de ideolojik temelli nefret söylemleri meydana gelmiştir. Bu aşamada Batı Bloğu ülkeleri propaganda faaliyetlerinde Sovyetler Birliği'ni hedef almıştır (Aşkan ve Mermer Üzümlü, 2020, s. 74). Sovyetler Birliği'nin olumsuz propagandasının hedefinde ise ABD olmuştur.

Nefret söylemi içeren ifadeler, hedef aldığı kişi veya grubu olumsuz yönde etkilemektedir. Bu ifadeler kimi zaman etnik ve dini kimliğin ön plana çıkarılmasıyla kimi zamanda geçmişte yapılan hataların hatırlatılmasıyla gerçekleşebilmektedir (Walker, 1994, s. 1). Son yıllarda Avrupa Birliği içerisinde aşırı sağ partiler tarafından göçmenlere karşı girişilen propaganda faaliyetlerinde doğrudan nefret söylemi kullanılabilmektedir. Özellikle Hollanda'daki Özgürlük Partisi (Partij voor de Vrijheid, PVV), İslam dinine karşı doğrudan nefret söylemine yer vermekte ve Müslüman göçmenlerin toplum tarafindan dışlanmasına yol açabilecek ifadelerde bulunmaktadır (Van Gent vd, 2014, s. 1778). Bu süreçte bazı siyasi partiler bireylerin etnik ve dini kimliği özelinde yürüttükleri propaganda faaliyetlerinde sık sık nefret söylemine yer verebilmektedir.

\section{Kıbrıs Barış Harekatı Sürecinde Türk-Yunan İlişkileri}

Yunanistan, 1821 yılında Osmanlı yönetimine karşı isyan etmişti (Aksan, 2010, s. 303). Avrupa ülkelerinden destek alan Yunanistan, 3 Şubat 1830 tarihinde Osmanlı Devleti'nden bağımsızlığını kazanmıştı. Yunanistan bağımsızlığını elde ettiği dönemde Mora Yarımadası'nda küçük bir toprak parçasına sahip olmuştu. Rum nüfusun önemli bir bölümü ise Osmanlı Devleti'nin egemenliğinde yaşamaya devam etmişti. Bu aşamada Yunanistan topraklarını genişletme odaklı bir siyaset içerisine girerek Osmanlı Devleti'ne karşı 1897 yılında OsmanlıYunan Savaşı ve 1912 yılında da Birinci Balkan Savaşı'na dahil olmuştu. İki ülke arasında yaşanan savaşlardan sonra Yunanistan topraklarını önemli ölçüde genişletmeyi başarmıştı. Yunanistan, Birinci Dünya Savaşı'nda da Osmanlı Devleti'ne karşı İtilaf Devletleri'nin yanında savaşa katılmıştı (Strachan, 2014, s. 352). Savaşta galip devletlerin arasında yer alan Yunanistan, 1919 yılında Osmanlı Devleti'nin Anadolu'da bulunan topraklarını işgale girişmişti.

Yunanistan, Mustafa Kemal Atatürk liderliğinde başlatılan Kurtuluş Savaşı'nda Türk ordusuna karşı ağır yenilgiler almış ve nihayetinde 1922 yılında Türkiye'de işgal ettiği tüm topraklardan çekilmişti. Yunanistan, 1923 yılında Türkiye ile imzalanan Lozan Barış Antlaşması ile savaş haline resmi olarak son vermişti. Her iki ülke arasında imzalan antlaşma gereği TürkiyeYunanistan Nüfus Mübadelesi gerçekleştirilmiş ve Türkiye'de yaşayan yüz binlerce Rum Yunanistan'a, Yunanistan'da yaşayan yüz binlerce Türk de Türkiye'ye göç ettirilmişti (Bozdağlığlu, 2014, s. 10). İki ülke arasında yaşanan savaşların son bulması üzerine Türkiye ve Yunanistan, 1920'li yıllardan itibaren ilişkilerini olumlu yönde geliştirme yoluna gitmişti. Özellikle Avrupa kıtasında güçlenen Adolf Hitler liderliğindeki Almanya ve Benito Mussolini liderliğindeki İtalya'ya karşı sınır güvenliklerini sağlamada ortak hareket etmeye çalışılmıştır.

İngiltere, 1960 yılında -Ağrotur ve Dikelya askeri üstleri haricinde- Kıbrıs adasından ayrılma kararı almıştı. Adada yaşayan Türk ve Rumların ortak idaresinde Kıbrıs Cumhuriyeti kurulmuş ve III. Makarios cumhurbaşkanı, Fazıl Küçük de cumhurbaşkanı yardımcısı olarak görev almıştı. İngiltere, Yunanistan, ve Türkiye de kurulan devletin garantör devletleri olmuştu. 
Kıbrıs Cumhuriyeti'nde 1963 yılında Kıbrıslı Türklere karşı gerçekleştirilen Kanlı Noel adı verilen saldırılar yaşanmıştı (Gülen, 2012, s. 399). Bu saldırılar Türkiye ve Yunanistan arasındaki ilişkilerin gerilmesine yol açmıştı. Diğer yandan Kıbrıs'in, Yunanistan ile birleşmesini savunan EOKA adlı örgütün ülkedeki faaliyetleri de Türkiye'nin ada ile ilgili endişelerini arttırmıştı. 15 Temmuz 1974 tarihinde Kıbrıs'ta darbe gerçekleştirilmiş ve III. Makarios görevinden uzaklaştırılmıştı (Gökçe, 2018, s. 48). Yaşanan tüm bu süreçte Türkiye ve Yunanistan savaşın eşiğine kadar gelmişti. Türkiye, 20 Temmuz 1974 tarihinde garantör devlet hakkını kullanarak adaya müdahale etmişti (Tarakçı, 2010, s. 17). 20 Temmuz 1974 tarihinde gerçekleştirilen müdahale, birinci harekât olmuş, 14 Ağustos 1974 tarihinde de ikinci harekât gerçekleştirilmişti. Müdahalenin ardından yönetimden EOKA'nın uzaklaştırılmasını sağlanmıştı. Türk ordusunun adaya müdahalesinden sonra Kuzey Kıbrıs'ta, 1975 yılında Kıbrıs Türk Federe Devleti (KTFD), 1983 yılında da Kuzey Kıbrıs Türk Cumhuriyeti (KKTC) kurulmuştu (Yılmaz, 2017, s. 95; Dolanbay, 2019, s. 853-854).

\section{Nefret Söyleminin Türkülere Yansıması}

Tüm toplumlar bağımsızlıklarını kazanmak için savaşlar vermiştir. Bu savaşlarda kazanılan zaferler milli bir değer olarak uzun yıllar belleklerde var olmuştur. Kıbrıs barış Harekâtı esnasında ve sonrasında şehitlere istinaden yazılan, kahramanlığı konu alan ve yaşanılan vahşeti gözler önüne sermeyi amaçlayan müzik eserleri, Türk toplumunun bu harekâtı unutmaması ve bu olayın nesillere aktarılması için önemli ölçüde kaynak görevi üstlenmiştir. Türkiye vatandaşlarının ve Kıbrıs Türklerinin anlatmak istedikleri "milliyetçilik" bu müzik eserleri ile akılda daha kalıcı ve insanları daha etkileyici bir hal almıştır.

"Milliyetçilik" söylem olarak tek bir bağlamda ele alınamayacak derecede farklı değişkenlerle şekillendiğinden tanımlanırken tek bir tanımdan bahsetmek imkânsızdır. Özellikle 60'lı yıllardan itibaren farklı disiplinlerdeki yapılan kültürel çalışmalar milliyetçilik çalışmalarına da kaymıştır. Milliyetçiliğin tanımlanması aşamasında net mutlak bir sonuca varılamadığından milliyetçilik ayrılıkçı bir hareket olmanın yanında, devletin birlik-beraberliğini koruma adına yapılan hareketler olarak da adlandirılabilmektedir (Kalaycı, 2007, s. 252). Bunun sonucunda farklı araştırmacılar tarafından ayrılıkçı hareketler "kötü" milliyetçiliği, devletin birlikberaberliğini korumayı hedefleyen hareketler ise "iyi” milliyetçilik olarak sınıflandırılmıştır.

Özkırımlı milliyetçiliği; "herşeyden önce bilincimize bir şekil veren, dünyayı anlamlandırmamızı sağlayan bir söylem; başka bir deyişle, toplu kimliklerimizi belirleyen, günlük konuşmalarımızı, davranış ve tutumlarımızı yönlendiren bir görme ve yorumlama, bir algılama biçimi” (2008, s. 285) olarak tanımlamaktadır.

Özkırımlı, çalışmasında milliyetçilik söyleminin üç temel özelliğini;

1- "Bu söyleme göre, millet her şeyden önce gelir, milletin çıkar ve değerleri diğer tüm çıkar ve değerlerden üstündür; 2- Milliyetçilik söylemi, milleti tek meşruiyet kaynağı olarak görür, burada kastedilen yalnızca siyasi meşruiyet değildir, "millet adına hareket etmek" normal koşullar altında hoş görülmeyecek hatta suç sayılabilecek pek çok davranış ve eyleme göz yumulmasını sağlar; 3- Milliyetçilik söylemi dünyayı ikili kategorilere ayırır, biz ve onlar, 
dostlar ve düşmanlar gibi, başka bir deyişle kimlikler ve karşı-kimlikler üretir, "bizi” "ötekilere" göre tanımlar, kendinden bir türlü emin olamadığı için de bu ayrımı hep canlı tutar" (2008, s. 285-286) şeklinde açıklamıştır. Toplumlar içerisinde ideolojiler, toplumda yer alan farklı dinamikler, tarih boyunca devam eden çatışmalar, anlaşmazlıklar ve düşmanlıklar bireylerin her an yaşam içerisinde iletişim araçları vasıtası ile karşılaştıkları söylemlerle bezenmiş olarak öne çıkmaktadır.

Genel olarak "kötü milliyetçilik" olarak adlandırılan milliyetçilik ayrıştırıcı kendinden olmayanı yerici, küçük düşürücü hakaret içerici bir söylem olarak karşımıza çıkmaktadır. Bu söylemde nefret ön plandadır. Milli beraberlik ilkesi söylemlerde sıklıkla dile getirilirken karşı tarafta yer alan kesim düşman görülmekte ve söylemlerle bu nefret açığa çıkmaktadır. Milliyetçilik gibi bazı ideolojik düşüncelerin bazı toplumlarda nefret söylemi gibi söylemlerle meşrulaştırıldığı görülmektedir.

Arapça kökenli olup, Türkçe anlamı itibari ile bir kimsenin kötülügünü, mutsuzluğunu istemeye yönelik duygu ve tiksinti, tiksinme anlamlarına gelen "nefret” sözcüğü, Latince'de "odium", İngilizce'de "hate" veya "hatred", Almanca'da "hassen" sözcükleri ile adlandırılmaktadır (Ataman, 2012, s. 50). Yumul'a göre; Nefret söylemi, söylem olarak üstünlük ilkesini pekiştirmeye yarar ve kendinden olmayanı “ötekileştirerek” bu farklı kimliklere haddini bildirmeyi amaçlar. Bu şekilde kendini hiyerarşik olarak üstün gören kimlik, ötekileştirilen farklı kimliklerin haklarını aramalarına da itirazda bulunur. Burada amaç aslında kendi üstünlüğünü, egemenliğini koruma çabasıdır (Yumul, 2013, s. 133).

\section{Metodoloji}

Kıbrıs Barış Harekâtı sırasında Türk-Yunan ilişkilerindeki gerilimin türkülere nasıl yansıdığını ortaya koymak çalışmanın temel amacını oluşturmaktadır. Böylece harekât döneminde türkülere yansıyan milliyetçilik söylemleri ve Yunanistan'a yönelik nefret söylemi hakkında bilgi verilmesi amaçlanmaktadır.

Çalışma;

- Kıbrıs Barış Harekâtı sırasındaki Türk-Yunan ilişkilerinde meydana gelen gerilimi yansitmasi,

- türkülerin propaganda amaçlı kullanılmaları hakkında bilgi vermesi,

- nefret söyleminin türkülere nasıl yansıdığını açıklaması gibi nedenlerden dolayı önem taşımaktadır.

Çalışmada müzik ve göstergebilim analizleri olmak üzere iki nitel araştırma yöntemi kullanılmıştır. Türkünün sözleri ABD'li dilbilimci Charles Sanders Peirce ve Fransız antropolog Claude Lévi-Strauss'un İkili Karşıtlık Modeli bağlamlarında analiz edilmiştir.

Gösterge, bir olgunun başka bir olgunun yerine kullanılmasını ve kullanıldığı olgu adına insanların zihinlerinde belirli algıları oluşturmasını ifade etmektedir. İnsan hayatında pek çok kavramın gösterge değeri bulunmaktadır. Çünkü insanlar iletişim boyutunda göstergeler 
üzerinden belirli anlamlandırmalar yapmaktadır. Göstergelerdeki anlam, insanların uzlaşıları neticesinde meydana gelmektedir (Erol, 2020, s. 301). Göstergebilim de insanlar tarafindan oluşturulan bu anlamlandırmaları incelemektedir (Tanyeri Mazıcı ve Çakı, 2018, s. 295). Diğer bir deyişle göstergebilim, insanlar tarafından göstergeler üzerinden inşa edilen anlamları ortaya çıkarmaya çalışan bir bilim dalıdır. Göstergebilim, 20. yüzyılın başlarında dilbilimciler Ferdinand de Saussure ve Charles Sanders Peirce'in dilbilimi alanında yaptığı çalışmalar ile ortaya çıkmıştır. İlerleyen süreçte de göstergebilim, hapsolduğu düşünülen dilbilimin (Gülada vd., 2019, s. 1086) sınırlarını aşarak, müzik, resim, fotoğraf, film, reklam vb. pek çok farklı konunun inceleme alanı haline gelmiştir. Bu süreçte Saussure ile birlikte göstergebilimin ilk modellerini oluşturan Peirce, göstergebilimin mantıksal boyutu üzerinde durmuştur. Peirce, nesne, gösterge ve yorumlayan olmak üzere üç kavram temelinde Anlamlandırma Modeli'ni meydana getirmiştir (Kalkan Kocabay, 2008, s. 19). Modelin temelinde görüntüsel gösterge, belirtisel gösterge ve simge olmak üzere üç alt başlık da oluşturulmuştur.

Görüntüsel gösterge, göstergenin temsil ettiği kavrama benzemesidir. Örneğin, bir kişinin fotoğrafı veya sesinin taklidi. Belirtisel gösterge, gösterge ve temsil ettiği kavram arasındaki ilişki boyutunun meydana gelmesidir. Diğer bir deyişle insanların bir durumu, başka bir durumu görerek anlamlandırmasıdır. Örneğin, uzaktan polis sirenin çalması, polisin gelmekte olduğunun işareti olması. Simge, gösterge ve kavram arasında herhangi bir benzerliğin olmadığ durumu ifade etmektedir. Gösterge, kavram kendisine benzediği için değil, toplumsal bir uzlaşı olduğu için kavramı temsil etmektedir. Örneğin, sözcükler, rakamlar (Fiske, 2017, s. 131).

Peirce'den sonra göstergebilimin gelişmesinde önemli rol oynayan kişilerden biri de Saussure'ün göstergebilim anlayışının etkisinde kalan ve alana yeni kavramlar kazandıran Fransız antropolog Claude Lévi-Strauss olmuştur. Lévi-Strauss'un göstergebilim anlayışı ikili karşıtlıklar üzerine temellenmiştir. Lévi-Strauss, toplumlar arasında ikili karşıtlıkların meydana geldiğini savunmaktadır (Lévi-Strauss, 2018a, s. 130). Bir toplumun, başka bir toplumu dışlaması ve onu "yaban" olarak nitelendirmesinin temelleri üzerine incelemelerde bulunmuştur. Nihayetinde Lévi-Strauss, bir toplumun yaban olarak adlandırılmasının onun ilkel bir toplum anlamına gelmediğini savunmuştur (Lévi-Strauss, 2017, s. 111). Lévi-Strauss, bir toplumun kendi kültürel değerlerini taşımayan toplumları dışlayabildiğini (Çetin vd., 2018, s. 39) ve onları yaban olarak nitelendirebildiğini iddia etmiştir. Aslında yaban olarak kabul edilen toplumların, kendilerini pek çok farklı alanda geliştirdiklerini belirtmiştir. Lévi-Strauss, bu süreçte bir toplumun olumlu soyut kavramları kendisi üzerinde, olumsuz ve zit soyut kavramları da yaban olarak tanımlanan toplumlar üzerinde somutladığını aktarmıştır (LéviStrauss, 2016, s. 27). Bu süreci Lévi-Strauss "somutlama mantığı" olarak adlandırmıştır.

Lévi-Strauss'un göstergebilim çözümlemesinde üzerinden durduğu bir diğer kavram da mitlerdir. Mit, bir toplumun çevresinde yaşanan gerçeklikleri açılama amacıyla ortaya koydukları öyküleri kapsamaktadır. Yani toplum kendi mitlerini oluşturmaktadır (LéviStrauss, 2018b, s. 40). Örneğin, bir toplumun çalışkan veya tembel olarak nitelendirilmesi, kültür içerisinde inşa edilen mitlerin sonucudur. Lévi-Strauss, mitlerin aslından gerçeklik taşımaktan ziyade gerçekleri yansıttığı düşünen illüzyonlar olduğunu savunmuştur (Lévi- 
Strauss, 2013, s. 37). Çünkü mitlerin toplum tarafından inşa edildiğini ve farklı toplumlarda bunun tersini savunan mitlerin meydana getirilebileceğini aktarmıştır.

\section{Analiz}

Çalışmanın bu bölümünde Kıbrıs'a Çıktık türküsünün müziksel ve göstergebilimsel analizi yapılmıştır. Sistematik ve duyumsal (işitsel) olarak müzik eserleri müziksel analiz bakımından incelendiğinde, müziksel özelliklerine göre sınıflandırılabilirler. Uzmanlar tarafından GTSM'de bulunan makamsal yapıya göre incelenecek eserlerin, inceleme sonucunda makam dizisi, karar sesi ve usul yapısı gibi özelliklerine ulaşılabilinir. Müzik eserlerinin karakteristik özelliklerini çıkarmak adına yapılan müzik analizleri "eserin teknik ve müzikal özelliklerini tanımak için yapılan analizler olup, esasen, etkili bir performansa ulaşabilmede teknik ve müzikal disiplinlere ilişkin güçlüklerin belirlenerek çözümlerinin üretildiği bir tanıma analizidir” (Bağçeci, 2003, s. 163).

\section{Kıbrıs'a Çıktık Türküsü'nün Müziksel Analizi}

1974 yılında Bedia Akartük tarafından Kıbrıs Barış Harekâtı sırasında Hülya Plakçılık’ tan çıkan 45’lik plakta yer alan “Kıbrıs’a Çıktık Kıbrıs'a” adlı eserin müziksel analizi aşağıda verilmiştir.

Tablo 1. Kıbrıs'a Çıktık Türküsü'nün Müziksel Analizi

\begin{tabular}{|c|c|c|c|c|c}
\hline Eserin Adı & Karar Perdesi & Formu & Makamı & Seyir Yapısı & Usulü \\
\hline Kıbrı'a Çıktık & La & Türkü & Uşşak & Çıkıcı & $2 / 4$ Nim Sofyan \\
\hline
\end{tabular}

Tablo 1'de görüldüğü üzere Kıbrıs'a Çıktık Şarkısı müzik yapısı bakımından incelendiğinde genel olarak türkünün cura, bağlama, zurna, zil, darbuka, çalgıları kullanılarak bir kutlama, dügün havasında icra edildiği gözlemlenmiştir. Türkü duyumsal olarak incelendiğinde Geleneksel Türk Müziği'nde makamsal olarak "Uşşak Makam Dizisi”nde icra edildiği gözlemlenmiştir. Türkünün karar sesi "La (Dügâh)”, güçlüsü “Re-Neva'dır. Makamsal olarak genişleme petse yegâh 'ta rast beşlisidir. Makam dizisi "Uşşak dörtlüsü”, "Buselik beşlisi" nin eklenmesinden oluşmuştur. Genelde türkülerin ritmik yapısında bulunan "2/4 (Nim Sofyan)" ritmik yapı kullanılmış olup, türküde makam dizisinin özelliklerinden olan seyir yapısında çıkıcı seyir yapısı kullanılmıştır.

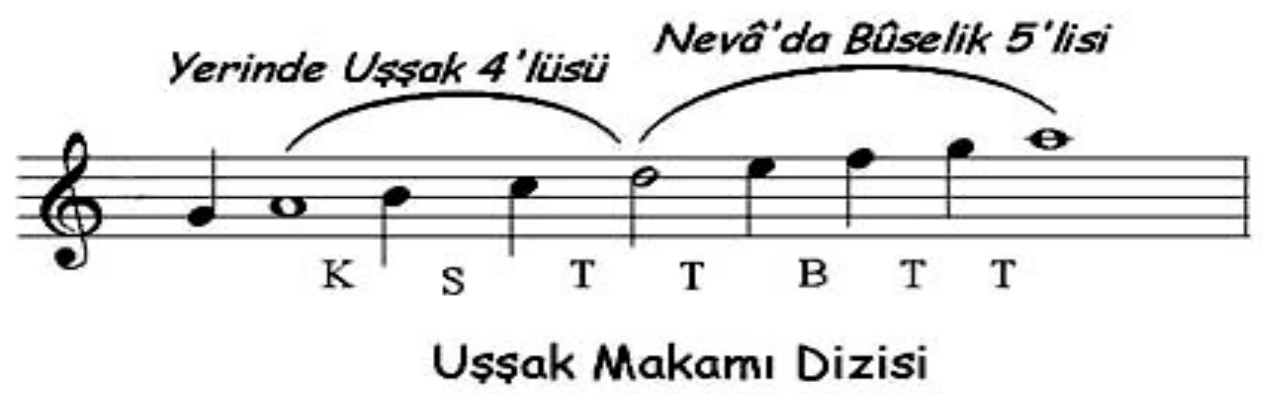

Resim 1. Kıbrıs'a Çıktık Türküsü’nün Makam Dizisi (Uşşak Makamı Dizisi) 
Uş̧̧ak Makamı basit makamlardandır. Uşşak tanım olarak âşık anlamında da kullanılmaktadır. Bu nedenle bu makama âşı makamı da denilmektedir. Uşşak makamı dügâh perdesinde karar eden, seyir olarak çıkıcı seyir özelliğe sahip basit makamlardandır. Tarihsel olarak bakıldığında geçmişte eser icralarında ve Geleneksel Türk Halk Müziğinde sıklıkla kullanıldığı gözlemlenen temel makamlardan biridir.

\section{Kıbrıs'a Çıktık Türküsü'nün Göstergebilimsel Analizi}

Kıbrıs'ı Çıktık türküsünün göstergebilimsel analizi, Anlamlandırma Modeli ve İkili Karşıtlıklar Modeli şeklinde ayrı başlıklar altında incelenmiştir.

\section{Kıbrıs'a Çıktık Türküsü'nün Anlamlandırma Modeli Üzerinden Analizi}

Türkünün birinci kıtası, görüntüsel gösterge açısından incelendiğinde, kıtada Yunan halkı ve Türk ordusu üzerinde durulduğu görülmektedir. Belirtisel gösterge açısından, Yunan halkının tarihte var olduğundan beri insanlık suçları işlediği iddia edilmektedir. Türk ordusunun Yunan ordusunun işlediği insanlık suçlarını durdurmak için harekete geçtiği aktarılmaktadır. Büyük Ata vurgusu ile Mustafa Kemal Atatürk'e atıfta bulunulmaktadır. Böylece Türk ordusunun Kıbrıs'ta kazandığı zafer ile Atatürk liderliğindeki Türk ordusunun Kurtuluş Savaşı'ndaki zaferleri hatırlatılmaktadır. Türk askeri, türküde Mehmet kelimesi ile simgeleştirilmektedir.

"Kükredik geliyoruz, kaçma kahpe Yunan, dur

Adem'i vuran budur, vur aslan Mehmet'im, vur

Jetler bomba ata ata, Mehmet koştu yeşil hata,

Müjde sana Büyük Ata, Kıbrıs'a çıktık, Kıbrıs'a"

Tablo 2. Birinci Kıtanın Anlamlandırma Modeli Bağlamında Analizi

\begin{tabular}{c|c}
\hline Görüntüsel Gösterge & Yunan, Mehmet, jetler, Büyük Ata, Kıbrıs \\
\hline Belirtisel Gösterge & $\begin{array}{c}\text { Türk ordusunun Kıbrıs'ta Yunan ordusunu mağlup etmesi, Yunan } \\
\text { ordusunun işlediği sözde suçlar nedeniyle Türk ordusu tarafından } \\
\text { cezalandırılmas1 }\end{array}$ \\
\hline Simge & Mehmet ismi Türk ordusu ile simgelenmektedir \\
\hline
\end{tabular}

Parçanın ikinci kıtası görüntüsel gösterge açısından Yunan halkına odaklanmaktadır. Belirtisel gösterge boyutunda, Yunan halkına yönelik doğrudan nefret söylemi inşa edilmektedir. Yunan halkının insani değerlerden uzak olduğu iddia edilmekte, bu nedenle Kıbrıs'ta yaşanan olaylardan doğrudan Yunan halkı sorumlu tutulmaktadır. Kıtada yer alan mermiler göstergesi, Türk ordusunun Kıbrıs'a müdahalesini simgelemektedir.

"Ne gezer sende namus, sende vicdan, merhamet

Var midır senin gibi adi bir millet

Beşparmak'tan daha kısa, ilk hedefimiz Mağusa

Mermileri basa basa, Kıbrıs'a çıktık, Kıbrıs'a" 
Tablo 3. İkinci Kıtanın Anlamlandırma Modeli Bağlamında Analizi

\begin{tabular}{|c|c|}
\hline Görüntüsel Gösterge & Namus, vicdan, merhamet, mermi, Kıbrıs \\
\hline Belirtisel Gösterge & $\begin{array}{c}\text { Yunan ordusunun, Kıbrıs'taki çatışmalardan ve insanlık } \\
\text { suçlarından sorumlu olduğu iddia edilmesi }\end{array}$ \\
\hline Simge & $\begin{array}{c}\text { Mermiler, Türk ordusunun Kıbrı's müdahalesini } \\
\text { simgelemektedir }\end{array}$ \\
\hline
\end{tabular}

Üçüncü kıtada görüntüsel gösterge olarak Kıbrıslı Rumların Kıbrıs'ta gerçekleştirdiği iddia edilen insanlık suçlarında, destek aldığı örgüt ve devletler üzerinde durulmaktadır. Belirtisel gösterge açısından, kıtada doğrudan isim verilmemekle birlikte Kıbrıslı Rumlar tarafından gerçekleştirilen askeri darbenin diş ülkeler tarafından desteklendiği iddia edilmektedir. Kıtada geçen süngünün pası kelimesi ile Türk ordusunun uzun bir süredir sıcak savaşa dahil olmadığı vurgulanmaktadır.

"Kime güvendin kıydın yüzlerce masum cana

Yalvar kurtarsın şimdi dayına amcana

Bir elinde tabancasl, bir elinde el bombast

Silindi süngünün pası, Kıbrıs'a çıktık, Kıbrıs'a"

Tablo 4. Üçüncü Kıtanın Anlamlandırma Modeli Bağlamında Analizi

\begin{tabular}{|c|c|}
\hline Görüntüsel Gösterge & Tabanca, el bombası, süngü, Kıbrıs \\
\hline Belirtisel Gösterge & $\begin{array}{c}\text { Yunan ordusunun Kıbrıs'ta insanlık suçu işlediği iddia edilmekte, bu } \\
\text { nedenle Türk ordusunun Kıbrı'a müdahale ettiği belirtilmektedir }\end{array}$ \\
\hline Simge & $\begin{array}{c}\text { Süngünün pas1, Türk ordusunun uzun bir sürenden beri sıcak savaşa } \\
\text { katılmamasını simgelemektedir }\end{array}$ \\
\hline
\end{tabular}

Dördüncü kıtada da görüntüsel gösterge açısından Yunan halkının dünya için büyük bir tehlike oluşturduğu iddia edilmektedir. Belirtisel göstergede ise Yunan halkının oluşturduğu iddia edilen tehlikeye karşı Türk ordusunun harekete geçtiği aktarılmaktadır. Bu süreçte de Türk ordusunun önemli başarılar elde ettiği belirtilmektedir. Kıtada Yunan halkına yönelik nefret söyleminin daha da yoğun olarak hissedildiği görülmektedir. Nitekim kıtada Yunan halkı, zehirli bir yılan ile simgeleştirilmektedir.

"Sen adi bir düşmansın, aşağılık Yunan'sın

Dünya'nın yüz karasısın, zehirli bir yılansın

Mağusa'da verdik mola, Larnaka'dan Limasol'a

Rumların hepsi kahrola, Kıbrıs'a çıktık, Kıbrıs'a" 
Tablo 5. Dördüncü Kıtanın Anlamlandırma Modeli Bağlamında Analizi

\begin{tabular}{|c|c|}
\hline Görüntüsel Gösterge & Düşman, Yunan, dünya, yılan, Kıbrıs \\
\hline Belirtisel Gösterge & $\begin{array}{c}\text { Yunan halkının yalnızca Türk halkı için değil, dünyanın } \\
\text { geneli için tehlikeli bir düşman olduğ iddia edilmektedir }\end{array}$ \\
\hline Simge & Yunan halkı, zehirli bir yılan olarak simgeleştirilmektedir \\
\hline
\end{tabular}

Türkünün beşinci ve son kitası görüntüsel gösterge açısından analiz edildiğinde, Yunan ordusunun masum sivilleri öldürdüğü iddia edilmektedir. Belirtisel gösterge açısından Türk ordusunun masum sivilleri kurtarmak için adaya müdahale ettiği belirtilmektedir. Kıtada Sakarya aslanları kavramı ile Sakarya Meydan Muharebesi'nde savaşan Türk askerlerine atıfta bulunulmaktadır. Nitekim Kıbrıs'ta mücadele veren Türk askerleri de aslan olarak simgeleştirilmektedir.

"Kadın, çocuk demedin öldürdün masumları

Kaçma korkak, geliyor Sakarya aslanları"

Tablo 6. Beşinci Kıtanın Anlamlandırma Modeli Bağlamında Analizi

\begin{tabular}{|c|c|}
\hline Görüntüsel Gösterge & Kadın, çocuk, ölüm, Sakarya aslanları \\
\hline Belirtisel Gösterge & $\begin{array}{c}\text { Yunan ordusunun Kıbrıslı Türk sivilleri katlettiği iddia edilmekte ve } \\
\text { Türk ordusunun da bu katliamı önlemek için harekete geçtiği } \\
\text { belirtilmektedir }\end{array}$ \\
\hline Simge & $\begin{array}{c}\text { Sakarya Meydan Muharebesi'nde savaşan Türk askerleri aslan olarak } \\
\text { simgelenmiştir }\end{array}$ \\
\hline
\end{tabular}

\section{Kıbrıs'a Çıktık Türküsü'nün İkili Karşıtlıklar Modeli Üzerinden Analizi}

Türkü, İkili Karşıtlıklar Modeli üzerinden ele alındığında genel olarak Türk ve Yunan toplumları üzerinden karşıtlıkların meydana getirildiği görülmektedir. Diğer bir deyişle türküde genelleştirme yapılarak, Türk milleti üzerinden olumlu, Yunan milleti üzerinden ise olumsuz soyut kavramlar somutlanmaktadır. Türküde Yunan halkı, hainlik, ölüm, düşmanlık; Türk halkı ise kahramanlık, dostluk ve cesaret soyut kavramları üzerinden sunulmaktadır. Bu şekilde Türk ordusunun Kıbrıs'a müdahalesinin haklı gerekçeler üzerinden gerçekleştiği kitlelere aktarılmaya çalışılmaktadır. 
Tablo 7. Türkünün Tamamının İkili Karşıtlıklar Modeli Üzerinden Analizi

\begin{tabular}{|c|c|}
\hline \multicolumn{2}{|c|}{ Somut Kavramlar } \\
\hline Türkler & Rumlar \\
\hline Kibrısl1 Türkler & Kibrıslı Rumlar \\
\hline Türk ordusu & Rum darbeciler \\
\hline \multicolumn{2}{|c|}{ Soyut Kavramlar } \\
\hline İyi & Kötü \\
\hline Yaşam & Ölüm \\
\hline Dost & Düşman \\
\hline Kahraman & Hain \\
\hline Cesur & Korkak \\
\hline
\end{tabular}

Türkünün tamamında Yunan halkına yönelik nefret söyleminin meydana getirildiği görülmektedir. Bu şekilde "Yunan halkı insanlık için büyük bir tehlikedir", "Yunan ordusu sivilleri katleder" ve "Yunan ordusu barbardır" şeklinde mitleri inşa edilmeye çalışılmaktadır. Mitler inşa edilirken, Türkiye ve Yunanistan arasında, 1919-1922 tarihleri arasında gerçekleşen sıcak savaşlara vurgu yapılmıştır. Yunan halkının, geçmişten beri Türk halkının düşmanı olduğu ve Kıbrıs meselesinde de düşmanlıklarını ortaya çıkardıkları iddia edilmiştir. Böylece Yunanistan'a yönelik Türk halkının milliyetçi duygularının güçlendirilmesi hedeflenmektedir.

\section{Sonuç}

Çalışma kapsamında ele alınan türküde doğrudan Rumlara yönelik olumsuz bir algının inşa edildiği görülmüştür. Türküde Rumlara yönelik olumsuz bir algı inşa edilirken genel olarak Rumların, düşman soyut kavramı üzerinden somutlandığı ortaya çıkarılmıştır. Rumlar yalnızca Türk milleti için değil, tüm insanlık için büyük bir tehdit olarak türküde lanse edilmiştir. Türkünün ilk kıtalarında, Rumlara karşı olumsuz bir algı meydana getirildikten sonra ilerleyen kıtalarda Rum ordularının Kıbrıs'ta masum sivilleri katlettiği iddia edilmiştir. Rumların yapmış olduğu tüm bu insanlık dışı eylemlere karşı Tük ordusunun harekete geçtiği vurgulanmış ve Rum ordusunu bozguna uğrattığı aktarılmıştır. Bu süreçte de Türk halkı, kahraman, dost, cesur soyut kavramları üzerinden somutlanmıştır. Türküde, Lévi-Strauss'un İkili Karşıtlıklar Modeli başarılı bir şekilde inşa edilmiş ve Türk halkının zihninde Rumların tehlikeli bir düşman olarak algılanmasına yol açılmıştır.

Türküde Yunan halkına yönelik inşa edilen olumsuz algıda, Kurtuluş Savaşı sırasında yaşanan Türk-Yunan savaşları da ön plana çıkarılmıştır. Böylece Türk milletinin, Yunan milleti ile geçmişten gelen bir düşmanlığı olduğuna vurgu yapılmış, ayrıca geçmişte Türk ordusu tarafından nasıl zaferler kazanılmışsa, Kıbrıs'ta da benzer zaferlerin kazanıldığı aktarılmıştır. Bu aşamada gerek geçmiş düşmanlıklar gerekse olumsuz somutlamalar yoluyla, Türk halkının zihninde "Yunan haklı barbardır", "Yunan ordusu katliam yapar" ve "Yunan halkı insanlığın düşmanıdır" şeklinde olumsuz algılar içeren mitlerin inşa edildiği ortaya çıkarılmıştır. Bu şekilde Türk ordusunun Kıbrıs'a müdahalesinin gerekçeleri açıklanmaya çalışılmıştır. Nitekim türküde Kıbrıs'a müdahalenin doğrudan meşruluğu savunulmuş ve Türk ordusunun adaya 
müdahalesi ile masum sivillerin kurtarıldığı aktarılmıştır. Türküde inşa edilen olumsuz algıyla Türk halkının milliyetçilik duygularının uyandırılması ve kamuoyunda müdahaleye yönelik güçlü bir desteğin oluşması hedeflenmiştir.

Çalışmada Bedia Akartürk'ün seslendirdiği Kıbrıs'a Çıktık adlı türkünün duyumsal olarak müziksel analizi de yapılmıştır. Analiz sonucunda eserin "La (Dügâh)” karar sesinden, "Uşşak dörtlüsü”ne, "Buselik beşlisi” nin eklenmesinden oluşan Geleneksel Türk Sanat Müziği makam dizilerinden "Uşşak Makamı Dizisi”nde, ritmik yapı bakımından “2/4 (Nim Sofyan)” usulünde icra edildiği sonuçlarına varılmıştır.

Çalışmada Kıbrıs Barış Harekâtı sırasında bestelen Kıbrıs'a Çıktık türküsünün propaganda amaçlı kullanımı analiz edilmeye çalışılmıştır. Çalışma türkülerin propaganda disiplini içerisindeki rolünü ortaya koyması bakımından önem taşımaktadır. Buna karşın elde edilen bulgular propaganda amaçlı bestelenen türkülerin kitlelerin fikirleri üzerinde ne gibi bir etki bıraktığını ortaya çıkaramamaktadır. Bu açıdan gelecek çalışmaların propaganda amaçlı bestelenen türkülerin kitleler üzerindeki etkisini inceleyen saha çalışmalarına yönelmesinin alana katkı sağlayacağı düşünülmektedir.

\section{Kaynakça}

Ataman, H. (2012). Nefret Suçlarını farklı yaklaşımlar çerçevesinden ele almak: etik, sosyopolitik ve bir insan hakları problemi olarak nefret suçları, Y. İnceoğlu (Ed.), Nefret Söylemi ve/veya nefret suçları içinde (s. 47-81). İstanbul: Ayrıntı.

Aksan, V. H. (2010). Kuşatılmış bir imparatorluk: Osmanlı Harpleri 1700-1870. Gül Çağalı Güven (Çev.), İstanbul: Türkiye İş Bankası Kültür.

Aşkan, H., \& Mermer Üzümlü, A. (2020). Soğuk Savaş döneminde Özgür Avrupa Radyosu'nu konu alan "Gerçekliğin Kuleleri" adlı kısa film üzerine inceleme. Anadolu Akademi Sosyal Bilimler Dergisi, 2(1), 71-92.

Bağçeci, S. E. (2003). Piyano eğitiminde müzikal analiz kavramı - kapsamı ve örnek klavye analizleri, Furat Üniversitesi Sosyal Bilimler Dergisi, 13(1), 159-176.

Bozdağlığlu, Y. (2014). Türk-Yunan nüfus mübadelesi ve sonuçları. Türkiye Sosyal Araştırmalar Dergisi, 180(180), 9-32.

Cortese, A. J. P. (2006). Opposing hate speech. The United States: Greenwood Publishing Group.

Çakı, C., \& Karaburun Doğan, D. (2018). Leyla Saz Hanım'ın sanat anlayışıly İttihat ve Terakki propagandası: Türk sanat müziği Vicdân-1 Muâzzam. Eurasian Journal of Music and Dance, 13, 66-81. 
Çetin, M., \& Gazi, M. A., Çakı, C. (2018). The Examination of the Anti-USA propaganda posters in the Iran Revolution according to Claude Lévi-Strauss' binary opposition. International Journal of Social Science, 1(3), 31-51.

Dolanbay, H. (2019). 1975-1984 arası gündem: Kıbrıs Barış Harekâtı ve Türkiye'nin dış politikası. Tarih ve Gelecek Dergisi, 5(3), 851-862.

Erol, E. G. (2020). Sovyetler Birliği'nde radyo yayıncılığının afişler üzerinden sunumu. TRT Akademi, 5(9), 292-313.

Fiske, J. (2017). İletişim çalışmalarına giriş. Süleyman İrvan (Çev.), 5. Basım. Ankara: Bilim ve Sanat.

Gazi, M. A., \& Çakı, C. (2019). II. Dünya Savaşı'nda çizgi filmlerin Mihver Devletleri tarafindan karşı propaganda amaçlı kullanımı. SineFilozofi, 4(8), 249-265.

Gökçe, E. (2018). 1974 Kıbrıs krizinde CHP-MSP koalisyon hükümetinin karar alma süreci. Ulisa: Uluslararası Çalışmalar Dergisi, 2(1), 41-60.

Gülada, M. O., Gazi, M. A. \& Çakı, C. (2019). Nazi propagandasının ulusal seferberlikte idealize ettiği Alman genç kızları: "Das Deutsche Mädel” dergisi üzerine inceleme. Erciyes İletişim Dergisi, 6(2), 1079-1100.

Gülen, A. (2012). İnönü hükümetleri'nin Kıbrıs politikası (1961-1965). Ankara Üniversitesi Türk Inkılâp Tarihi Enstitüsü Atatürk Yolu Dergisi, 13(50), 389-428.

Jowett, S. G. \& O'donnell, V. (2014). Propaganda \& persuasion. The United States: Sage.

Karaca, M. (2018). İtalyan propagandasında kült lider olgusu: "Il Duce" Benito Mussolini. Gümüşhane Üniversitesi İletişim Fakültesi Elektronik Dergisi, 6(2), 1203-1220.

Kalkan Kocabay, H. (2008). Tiyatroda göstergebilim. İstanbul: E.

Karaburun Doğan, D., Sayan, Ş., \& Çakı, C. (2017). The Analysis on election music and propaganda posters of political parties in 1999 general and local elections in Turkey, $\mathrm{H}$. Arapgirlioğlu, A. Atik, R. L. Elliott, E. Turgeon (Ed.), In 2. Researches on science and art in 21st century Turkey (p. 179-186). Ankara: Gece.

Karaburun Doğan, D., Çakı, C. (2019). Kıbrıs Barış Harekâtı'nda müziğin milliyetçilik inşasında propaganda amaçlı kullanılması: Girne'den yol bağladık Anadolu'ya şarkısı üzerine inceleme. Eurasian Journal of Music and Dance, 14, 214-229.

Kuş, O. (2016). Dijital nefret söylemini anlamak: Suriyeli muilteci krizi örnek olayı baglamında BBC World Service Facebook sayfasına gelen yorumların metin madencilı̈̆i teknı̆gi ile analizi. İstanbul Üniversitesi İletişim Fakültesi Dergisi, 51, 97-121. 
Lévi-Strauss, C. (2013). Mit ve anlam, Gökhan Yavuz Demir (Çev.), İstanbul: İthaki.

Lévi-Strauss, C. (2016). Irk, tarih ve kültür, Haldun Bayrı, Reha Erdem, Arzu Oyacıŏlu, Işık Ergüden (Çev.), 7. Basım, İstanbul: Metis.

Lévi-Strauss, C. (2017). Hepimiz yamyamız, Haldun Bayrı (Çev.), 2. Basım, İstanbul: Metis.

Lévi-Strauss, C. (2018a). Yaban düşünce, Tahsin Yücel (Çev.), İstanbul: Yapı Kredi.

Lévi-Strauss, C.(2018b). Hüzünlü dönenceler, Ömer Bozkurt (Çev.), 6. Baskı, İstanbul: Yapı Kredi.

Ozulu, S. (2014). Nefret söyleminin engellenmesinde siyaset kurumu. Dicle Üniversitesi İktisadi ve İdari Bilimler Fakültesi Dergisi, 4(7), 15-29.

Özkırımlı, U. (2008). Milliyetçilik kuramları eleştirel bir bakış, Ankara: Doğu Batı.

Strachan, H. (2014). Birinci Dünya Savaşı, Ümit Hüsrev Yolsal (Çev.), İstanbul: Say.

Tanyeri Mazıcı, E., \& Çakı, C. (2018). Adolf Hitler'in korku çekiciliği bağlamında kamu spotu reklamlarında kullanımı. Erciyes İletişim Dergisi, 5(3), 290-306.

Tarakçı, M. (2010). Kıbrıs Barış Harekâtı. İstanbul: Hiperlink.

Tate, T. (1998). Modernism, history and the First World War. The Great Britain: Manchester University.

Van Gent, W. P., Jansen, E. F., \& Smits, J. H. (2014). Right-wing radical populism in city and suburbs: an electoral geography of the Partij Voor de Vrijheid in the Netherlands. Urban Studies, 51(9), 1775-1794.

Vardal, Z. B. (2015). Nefret söylemi ve yeni medya. Maltepe Üniversitesi İletişim Fakültesi Dergisi, 2(1), 132-156.

Voigtländer, N., \& Voth, H. J. (2015). Nazi indoctrination and anti-semitic beliefs in Germany. Proceedings of the National Academy of Sciences, 112(26), 7931-7936.

Waldron, J. (2012). The Harm in hate speech. The United States: Harvard University.

Walker, S. (1994). Hate speech: the history of an American controversy. The United States: U of Nebraska.

Weber, A. (2009). Nefret söylemi el kitabı, Metin Çulhaoğlu (Çev.), Strazburg: Avrupa Konseyi. 
Yılmaz, H. (2017). Kıbrıs Barış Harekâtı ve sonuçları. İnönü University International Journal of Social Sciences (INIJOSS), 6(1), 87-98.

Yılmaz, M. B. (2020). İkinci Dünya Savaşı'nda Japon medyasının ABD'ye yönelik faaliyetleri: Tokyo Rose radyo yayınları üzerine inceleme. Insan ve Toplum Bilimleri Araştırmaları Dergisi, 9(1), 541-563 .

Yumul, A. (2013). Nefret suçu ya da ölü vicdanlar ülkesi. M. Çınar (Ed.), Medya ve nefret söylemi kavramlar mecralar tartışmalar içinde (s. 127-134). İstanbul: Hrant Dink. 